\title{
Aquaculture-derived trophic subsidy boosts populations of an ecosystem engineer
}

\author{
C. A. White ${ }^{1,2,5, *}$, R. J. Bannister ${ }^{3}$, S. A. Dworjanyn ${ }^{4}$, V. Husa ${ }^{3}$, P. D. Nichols ${ }^{2}$, \\ T. Dempster ${ }^{1}$
}

\author{
${ }^{1}$ School of BioSciences, University of Melbourne, Parkville, Victoria 3010, Australia \\ ${ }^{2}$ Oceans and Atmosphere, Commonwealth Scientific and Industrial Research Organization, Castray Esplanade, Hobart, \\ Tasmania 7000, Australia \\ ${ }^{3}$ Institute for Marine Research, PO Box 1870, 5817 Bergen, Norway \\ ${ }^{4}$ National Marine Science Centre, Southern Cross University, Coffs Harbour, New South Wales 2450, Australia \\ ${ }^{5}$ Present address: Institute for Marine and Antarctic Studies, University of Tasmania, Nubeena Crescent, Taroona, \\ Tasmania 7053, Australia
}

\begin{abstract}
Environmental management of coastal aquaculture is focused on acute impacts of organic and nitrogenous wastes close to farms. However, the energy-rich trophic subsidy that aquaculture provides may create cascades with influences over broader spatial scales. In a fjord region with intensive fish farming, we tested whether an ecosystem engineer, the white urchin Gracilechinus acutus, was more abundant at aquaculture sites than control sites. Further, we tested whether diets influenced by aquaculture waste altered reproductive outputs compared with natural diets. Urchins formed barrens at aquaculture sites where they were 10 times more abundant (38 urchins $\mathrm{m}^{-2}$ ) than at control sites $\left(4\right.$ urchins $\left.\mathrm{m}^{-2}\right)$. Urchins were on average $15 \mathrm{~mm}$ larger at control sites. In the laboratory, urchins fed aquafeed diets had 3 times larger gonad indices than urchins fed a natural diet. However, their reproduction was compromised. Eggs from females fed an aquafeed diet had $13 \%$ lower fertilisation success and $30 \%$ lower larval survival rates at $10 \mathrm{~d}$ compared with females fed a natural diet. A reproductive output model showed that enhanced numbers of $10 \mathrm{~d}$ old larvae produced by the dense aquaculture-associated aggregations of G. acutus will supersede any detrimental effects on reproduction, with larval outputs from aquaculture sites being on average 5 times greater than control sites. The results show that aquaculture waste can act as a trophic subsidy in fjord ecosystems, stimulating aggregations of urchins and promoting the formation of urchin barrens. Where finfish aquaculture is concentrated, combined effects on the wider environment may produce ecosystem-level consequences.
\end{abstract}

KEY WORDS: Aquaculture - Echinus acutus $\cdot$ Gracilechinus acutus $\cdot$ Larval survival · Norway · Population density $\cdot$ Reproductive output $\cdot$ Sea urchin $\cdot$ Trophic subsidy $\cdot$ Urchin barren

\section{INTRODUCTION}

Trophic subsidies occur via the flow of energy between ecosystems, as both matter and organisms (Larsen et al. 2016). Subsidies influence food web and ecosystem dynamics in recipient environments, with the quantity and quality of the subsidy exerting a strong effect on the overall impact (Marcarelli et al.

${ }^{*}$ Corresponding author: camille.white@utas.edu.au
2011). While trophic subsidies occur naturally, increasingly, anthropogenic subsidies are driving changes to ecosystems and food webs by altering the distribution, abundance, growth and reproduction of consumers in recipient environments (Marczak et al. 2007, Oro et al. 2013). Given over half of the human population lives within $60 \mathrm{~km}$ of the coast (UNEP 2016), it is unsurprising that anthropogenic subsidies

(C) The authors 2018. Open Access under Creative Commons by Attribution Licence. Use, distribution and reproduction are unrestricted. Authors and original publication must be credited. 
are common in marine systems. Examples include the bulk input of nitrogenous and organic wastes (Gorman et al. 2009), fisheries discards (Oro et al. 2013) and, increasingly, waste products from finfish and shellfish aquaculture (Fernandez-Jover et al. 2011a).

Aquaculture of carnivorous fish in coastal waters releases dissolved nitrogen and organic carbon to receiving environments, particularly through waste feed and faecal material (Carroll et al. 2003, Bannister et al. 2014). Outputs from cage aquaculture can drive community change in the immediate surrounds of a farm, in both benthic (Keeley et al. 2012) and pelagic (Riera et al. 2014) systems, often leading to a proliferation of opportunistic taxa (Macleod et al. 2004, Kutti et al. 2007). Less well understood are the impacts of aquaculture subsidies on a broader scale, where waste may be delivered in quantities more readily assimilated by the wider ecosystem, with potential consequences for the marine food web (Bannister et al. 2016, Broch et al. 2017). As aquafeed inputs are high in lipid, waste from aquaculture is an energy-rich resource in the marine environment, with wild fauna benefiting energetically from consumption (Parrish 2009). Wild marine fauna, including fish (FernandezJover et al. 2011b) and mobile invertebrates (Olsen et al. 2012, White et al. 2017) consume aquaculture waste. Proxy fitness measures, such as somatic and liver condition indices, are higher in farm-associated wild fish than wild fish caught distant from farms (Dempster et al. 2011). However, potential repercussions to the fitness of individuals and dynamics of populations that receive aquaculture-derived trophic subsidies remain unexplored, as are the mechanisms through which subsidies could cascade through ecosystems on a broader scale.

As well as bulk quantity, the quality of a trophic resource determines ecosystem-level outcomes (Marcarelli et al. 2011). Modern aquaculture feeds have lipid compositions that are relatively alien in the marine environment, as they are rich in shorter chain $\left(\mathrm{C}_{18}\right)$ polyunsaturated fatty acids (PUFA) derived from terrestrial vegetable oils and meals, and low in omega-3 long-chain ( $\geq \mathrm{C}_{20}$ ) PUFA ( $n-3$ LC-PUFA), produced by marine phytoplankton (Turchini et al. 2009, Nichols et al. 2014). As wild marine fauna typically have diets high in $n$-3 LC PUFA (Twining et al. 2016), high consumption of aquaculture waste represents a substantial quantitative and qualitative biochemical shift in dietary intake. A shift in nutritional quality of diet, combined with other challenges associated with near farm environments, such as heavy metals, synthetic chemicals and persistent organic pollutants (Burridge et al. 2010, Samuelsen et al.
2015), may supersede fitness benefits associated with the bulk organic subsidy. In this manner, aquaculture outputs could function as an ecological trap, whereby individuals are attracted to the trophic subsidy, with detrimental fitness and reproductive consequences (Robertson \& Hutto 2006, Hale \& Swearer 2016).

Norway is the largest producer of farmed Atlantic salmon Salmo salar globally, with an annual production exceeding 1.3 million $t$ and 990 licensed farms in 2015 (Directorate of Fisheries 2016). In total, the industry releases approximately $60000 \mathrm{t}$ of carbon, $34000 \mathrm{t}$ of nitrogen and $9750 \mathrm{t}$ of phosphorus into fjord and coastal ecosystems (Taranger et al. 2015), where it is available as a trophic resource for wild fauna. Farms in Norway attract wild fish with an estimated 12000 t of wild fish aggregating around farms on any given day in summer (Dempster et al. 2009). Benthic productivity can also increase in farm areas, particularly in deep fjords where productivity is limited and the addition of organic waste contributes significantly to food supply (Kutti et al. 2007, Olsen et al. 2012).

Sea urchins are ecosystem engineers in many coastal ecosystems, altering habitat structure and function through grazing, with ramifications for the entire food web (Graham 2004, Ling 2008). The white sea urchin Gracilechinus acutus (formerly Echinus acutus) is an ecosystem driver in the Norwegian fjords, largely due to high grazing pressure on kelp vegetation, with barren formation observed in areas with dense aggregations (Husa et al. 2014). G. acutus is omnivorous and consumes mussel spat, epibenthic invertebrates and detritus, and can capitalise on aquaculture waste as a trophic resource (White et al. 2017). Whether consuming aquaculture waste improves or reduces fitness of $G$. acutus is at present unknown.

We investigated the effect of aquaculture on population densities of wild $G$. acutus and tested the physiological and reproductive consequences of consuming an aquaculture-derived trophic subsidy. Population densities and reproductive outputs were then combined to model the consequences of aquaculture on populations of $G$. acutus. Current monitoring regimes and management of aquaculture outputs are generally focused on acute impacts directly associated with cage or lease zones. If the outcome of aquaculture subsidies is to drive broad-scale population growth of a species able to act as an ecosystem engineer, energy flow through coastal fjord ecosystems may be altered, with this work having immediate relevance in assessing ecosystem effects of salmon aquaculture. 


\section{MATERIALS AND METHODS}

\section{Urchin densities close to and distant from aquaculture sites}

In a region of western Norway with intensive Atlantic salmon farming (Masfjorden; Fig. S1 in the Supplement at www.int-res.com/articles/suppl/q010 p279_supp.pdf), we tested whether abundance and size of the white urchin Gracilechinus acutus differed between aquaculture and control sites. In August 2015, we assessed urchin abundance per $\mathrm{m}^{2}$ and collected urchins to compare mean size at 4 salmon farm sites and control sites $1.5-2.0 \mathrm{~km}$ away from the nearest farm. Counts were done within 6 randomly placed $1 \mathrm{~m}^{2}$ quadrants along a $50 \mathrm{~m}$ transect line at 5-10 $\mathrm{m}$ depth. At farm sites this was done in the subtidal zone between shoreline and farm and as close as possible to an active cage. The first 50 urchins encountered per site were collected and measured dorsoventrally at their widest point using callipers.

\section{Effects of aquaculture waste feed in diets on the reproductive outputs and physiological responses of urchins}

To determine whether the level of waste feed from aquaculture contained in urchin diets affected spawning, subsequent development of larvae and their survival, we fed urchins with manipulated diets and followed the fate of the larvae. Urchins were collected on SCUBA from Masfjorden, Hordaland, Norway from a depth of 5-15 $\mathrm{m}$ in January 2015 with the collection point $>5 \mathrm{~km}$ from the nearest active farm. Sixteen animals were randomly assigned to 1 of 15 aquaria (200 l) and supplied with flow-through seawater at ambient temperature and salinity (approximately $8.9^{\circ} \mathrm{C}$ and $34.8 \%$ ). Each of the aquaria were given one of 3 diets for a period of $10 \mathrm{wk}$, with 5 replicate aquaria per diet. Diet 1 contained a current commercial Atlantic salmon Salmo salar feed (farm feed), Diet 2 was a 1:1 combination of the commercial feed and natural materials (composite feed) and Diet 3 contained only natural materials (natural feed). 'Natural' was defined as anything urchins were observed feeding on in the wild, or found within gut contents, which were analysed from randomly collected wild urchins prior to commencing the experiment. This included macroalgae, including fucoid brown algae Fucus vesiculosus and sugar kelp Sacharina lattissima $(70 \% \mathrm{w} / \mathrm{w})$, mixed red algae $(20 \% \mathrm{w} / \mathrm{w})$, encrusting flora and fauna from kelp (including corallines, epiphytic red algae and bryozoans, 5\% w/w), mussel spat, gastropods and various crustaceans $(5 \% \mathrm{w} / \mathrm{w})$, all collected by diver from the shallow subtidal zone.

Artificial diets for urchins were manufactured following the exact methodology outlined in White et al. (2017). Samples of all 3 diets were retained and stored at $-80^{\circ} \mathrm{C}$ for subsequent analysis. Sea urchins were held for $5 \mathrm{~d}$ without food prior to the start of the feeding trial to standardize hunger. Diets were analysed for carbon, nitrogen and lipid to establish comparative energetics of each diet (Table 1). Animals were fed once every $3 \mathrm{~d}$ during the experiment, which ensured they were never food limited. All mortalities were recorded.

After 10 wk of feeding, urchins were induced to spawn by injection of $2-3 \mathrm{ml}$ of $1.0 \mathrm{M} \mathrm{KCl}$. Eggs from gravid females were collected in $500 \mathrm{ml}$ beakers of filtered seawater. Wild males were collected on the morning of the spawning event and induced to spawn, with sperm collected on petri dishes using dry pipettes. Eggs were subsequently checked for shape and integrity and sperm for motility. The eggs of each female were fertilized by the sperm from multiple ( $n=5)$ males. Five lots of 200 eggs from each female were placed in $100 \mathrm{ml}$ sterile glass rearing pots. The volume of sperm required to achieve a sperm:egg ratio of 1000:1 was determined through haemocytometer counts. The sperm was briefly activated in filtered seawater and added to containers holding the eggs. Rearing containers were left for $10 \mathrm{~min}$ for fertilisation to occur, then flushed to remove excess sperm. Rearing containers were maintained at a temperature of $9.0^{\circ} \mathrm{C}$ (equivalent natural fjord temperature) and flushed daily with filtered seawater.

Each rearing container was scored for percent fertilisation success ( $2 \mathrm{~h}$ post-fertilisation) and percent survival to $10 \mathrm{~d}$ post-fertilisation by counting the number of viable eggs and larvae in the rearing con-

Table 1. Carbon, nitrogen and total lipid values for experimental dietary treatments. $n-3: n-6$ refers to the ratio of omega-3 polyunsaturated fatty acids to omega- 6 polyunsaturated fatty acids within dietary treatments. \% cholesterol is given as the $\%$ of total lipid 45

\begin{tabular}{|lccc|}
\hline & Aquafeed & Composite & Natural \\
\hline \% carbon & 48.0 & 21.8 & 9.1 \\
\% nitrogen & 2.7 & 3.0 & 0.7 \\
\% total lipid & 13.3 & 7.9 & 0.4 \\
\% cholesterol & 0.07 & 0.02 & 0.009 \\
$n$-3: $n$-6 & 0.96 & 0.95 & 1.70 \\
\hline
\end{tabular}


tainers. Photographs of fertilised eggs and larvae post-metamorphosis were taken using an Olympus SZX7 dissecting microscope, Olympus DP26 digital camera and cellSens Entry v1.7 image capture software. Diameters of 30 fertilized eggs were measured from each rearing container using Image $(\mathrm{NIH})$. The length and symmetry of $10 \mathrm{~d}$ old larvae were recorded using the criteria of Sheppard-Brennand et al. (2010).

At the conclusion of the experiment, gonad indices were obtained for 5 randomly selected urchins from each tank. Urchins were patted down to remove excess external water and weighed. Gonads were removed from the test and weighed. An index measure was obtained by dividing total weight by the weight of the gonad. From 3 urchins per tank, 1 gonad was fixed in Bouin's solution for histological sectioning. Gonads were washed, dehydrated in ethanol and soaked in a haemotoxylin, erythrosin and saffron stain, then embedded in wax and cut into $3 \mu \mathrm{m}$ sections before being set on slides for examination. The remaining 4 gonads were freeze dried, with total lipid, n-3 LC-PUFA and n-6 PUFA content measured using techniques described in White et al. (2017).

\section{Statistical analysis}

We tested whether abundance and size of urchins differed between aquaculture and control locations using ANOVA with location ('aquaculture' or 'control') as a fixed factor. The effects of diet on gonad index, lipid content and respiration were tested using ANOVA with diet as a fixed factor. For analysis of larval success parameters (fertilisation success, larval survival, egg size, larval size and symmetry), a single mean data point for each female derived from larvae across all 5 rearing containers was determined. We used a PERMANOVA (Anderson et al. 2008) to test the overall effect of diet across the multiple parameters of larval success (using PRIMER v7 and its complementary software package PERMANOVA+ (v7)) Monte Carlo (MC) p-values of 0.05 were used to indicate significant differences between treatments. SIMPER analysis was subsequently used to assess the contribution of each parameter to the dissimilarity between treatments. Following this, 1-way ANOVA was used to test whether fertilisation success, larval survival, egg size, larval size and symmetry varied with diet. For larval success parameters, both 2-way multivariate and univariate analysis was performed first with tank as a factor nested within diet. Where the effect of tank was highly non-significant ( $p \geq 0.2)$, the design was collapsed and effects examined through 1-way analysis with diet as a fixed factor (Quinn \& Keough 2002). All data were checked for assumptions of normality and homogeneity according to Quinn \& Keough (2002), and data were square root transformed where appropriate. Where diets differed significantly $(\mathrm{p} \leq 0.05)$, Tukey-Kramer post-hoc tests were conducted to detect differences among means.

\section{Reproductive output model}

We modelled the reproductive outputs of farmassociated and control urchin populations in Masfjord by using our data on the abundance, size and larval fitness after exposure to different diet types. The number of $10 \mathrm{~d}$ old urchin larvae $(N)$ produced by $1 \mathrm{~m}^{2}$ of habitat in farm and non-farm conditions was calculated as:

$$
N=\left(D_{\mathrm{U}} / S\right) \times\left(E / F_{\mathrm{S}}\right) \times L_{\mathrm{S}}
$$

where $D_{\mathrm{U}}$ represents the density of urchins per $\mathrm{m}^{2}$ observed from field data, $S$ represents the male: female ratio (assumed to be 0.5 for all scenarios) and $E$ represents the number of eggs released by each female, which is size dependent. We assumed the number of eggs released by urchins increased with size and was directly proportional as for other invertebrates (Levitan 1991). Fecundity estimates from the experiment indicated that a ripe $5 \mathrm{~cm}$ female produced 5 million eggs, which was the value used to scale size-dependent egg release. $F_{\mathrm{S}}$ and $L_{\mathrm{S}}$ represent the fertilization and larval survival rates obtained through the experiment. $N$ was calculated using experimental values obtained for both aquaculture feed and composite diets for the 'farm' conditions, while values for the natural diet were used to calculate $N$ for 'non-farm' conditions.

\section{RESULTS}

\section{Urchin densities close to and distant from aquaculture sites}

Abundance of urchins was 3 to 100 times greater at aquaculture than control sites $\left(F_{4,44}=31.6, \mathrm{p}<\right.$ 0.0001) (Table S1). All 4 aquaculture sites were characterised by high densities of urchins $\left(29-47 \mathrm{~m}^{-2}\right)$ and urchin barrens, compared with lower densities $\left(0.2-13.2 \mathrm{~m}^{-2}\right)$ in control locations where only 1 of 4 
sites could be characterised as an urchin barren (Fig. 1A). Mean test diameters were consistently smaller (4-25 $\mathrm{mm}$ on average) at aquaculture than control sites $\left(F_{3,390}=33.2, \mathrm{p}<0.0001 ;\right.$ Fig. 1B). There was also a significant location effect for both abundance $\left(F_{4,44}=3.2, \mathrm{p}<0.04\right)$ and test diameter $\left(F_{3,390}=\right.$ $71.5, \mathrm{p}<0.0001)$ of urchins.

\section{Effects of aquaculture waste feed in diets on the reproductive outputs and physiological responses of urchins}

Mortality of adults throughout the $10 \mathrm{wk}$ exposure period was uniform across dietary treatments and did not exceed 4 individuals from any tank. Females were successfully induced to spawn from each treatment. Diet altered larval survival and growth parameters $\left(F_{2,10}=4.3, \mathrm{p}(\mathrm{MC})=0.03\right)$ (Tables $\left.\mathrm{S} 2-\mathrm{S} 4\right)$, with \% survival $10 \mathrm{~d}$ post fertilisation, fertilisation success and echinopluteal length identified by SIMPER as contributing to over $70 \%$ of dissimilarity between diets. Fertilisation success, egg diameter and echinopluteal length all increased linearly from aquafeed to composite to natural dietary treatments, while larval asymmetry decreased (Fig. 2). Survival of larvae $10 \mathrm{~d}$ post-fertilisation varied with dietary treatment $\left(F_{2,10}\right.$ $=7.0, \mathrm{p}=0.01$ ), with survival of larvae from the natural treatment over $30 \%$ higher than the aquafeed
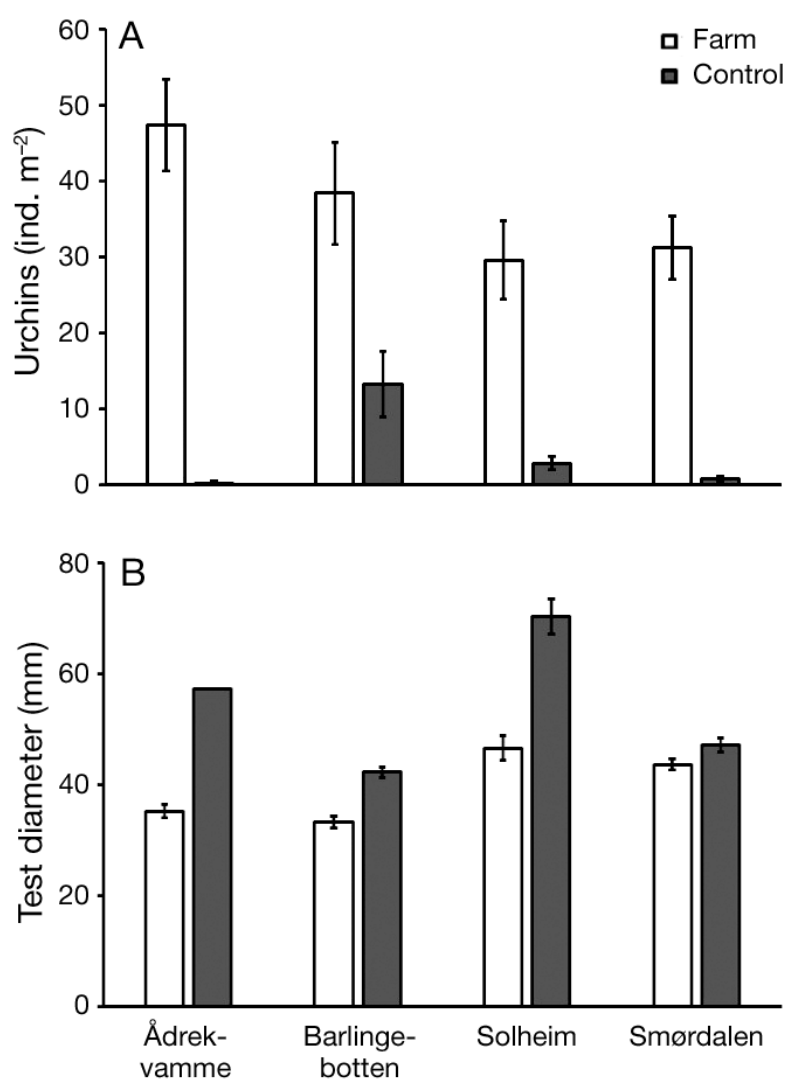

Fig. 1. Results from the field survey of Gracilechinus acutus (A) urchin abundance $\left(\mathrm{m}^{-2}\right)$ and (B) average test size \pm SE at control and farm locations across 4 sites in Masfjord, Norway
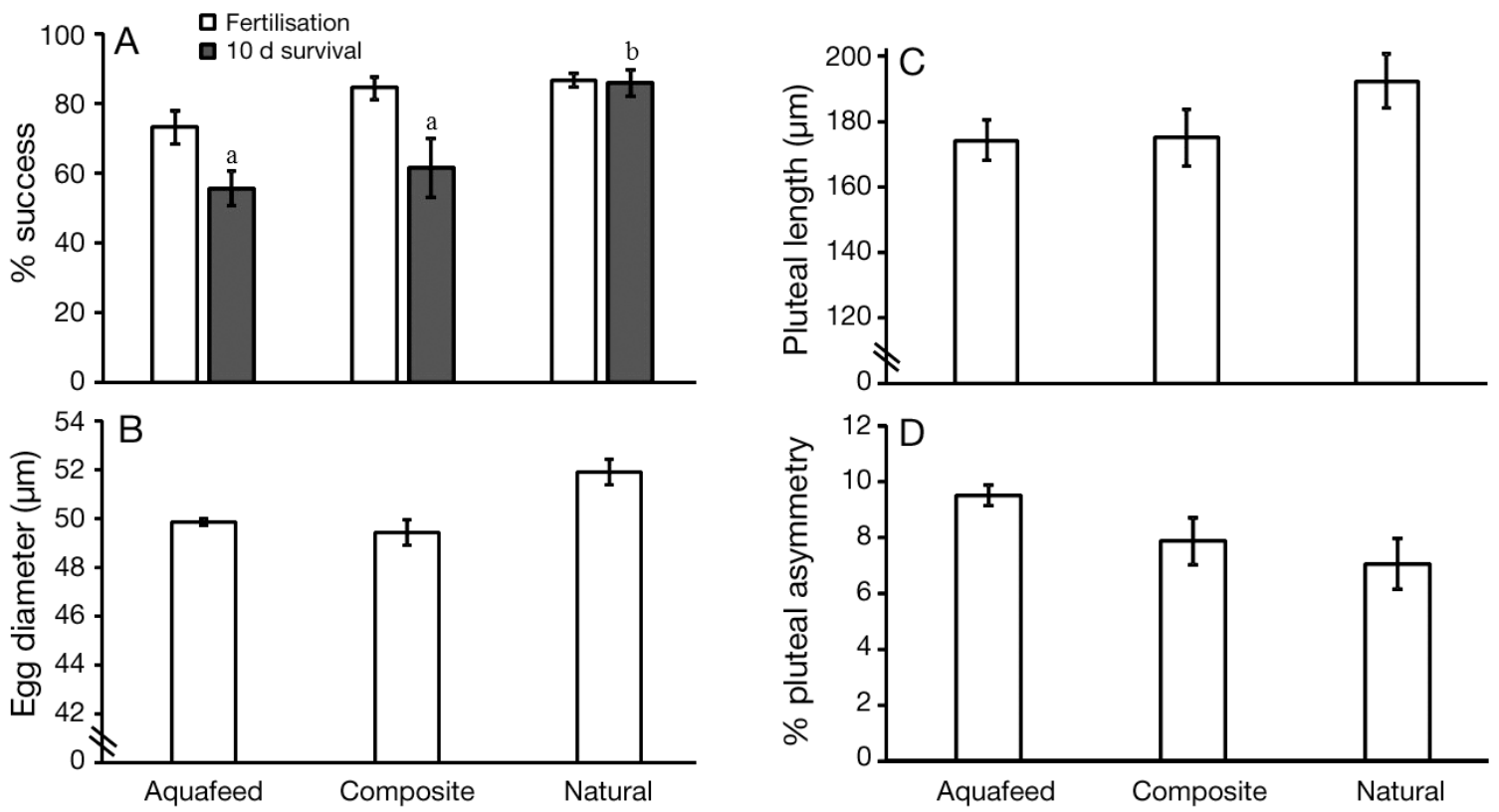

Fig. 2. Mean $( \pm \mathrm{SE})$ effects of dietary treatment on larval success and development of Gracilechinus acutus measured as (A) \% fertilisation success and \% survival $10 \mathrm{~d}$ post fertilisation, (B) egg diameter $(\mu \mathrm{m}),(\mathrm{C})$ pluteal length, being the average length of the pluteal arms $(\mu \mathrm{m})$ and $(\mathrm{D}) \%$ asymmetry obtained by the difference in length of pluteal arms. Superscript letters in (A) denote significant treatment effects 
treatment and $24 \%$ higher than the composite treatment (Fig. 2).

Urchins fed aquafeed diets had 1.5 and 4.0 times larger gonads compared with the composite and natural diets, respectively $\left(F_{2,12}=17, \mathrm{p}<0.0001\right.$; Fig. 3A) (Table S5). When examined on a per unit mass basis, total lipid content in gonads or eggs did not differ with diet, with gonads ranging from 11.1 to $13.7 \mathrm{mg} \mathrm{g}^{-1}$ total lipid dry mass and eggs slightly higher at $13.0-18.1 \mathrm{mg} \mathrm{g}^{-1}$ total lipid dry mass (Fig. 3B). Likewise, the $n-3$ LC-PUFA: $n-6$ PUFA ratio in gonads $\left(F_{2,12}=2.0, \mathrm{p}=0.2\right)$ and eggs $\left(F_{2,6}=0.1, \mathrm{p}=\right.$
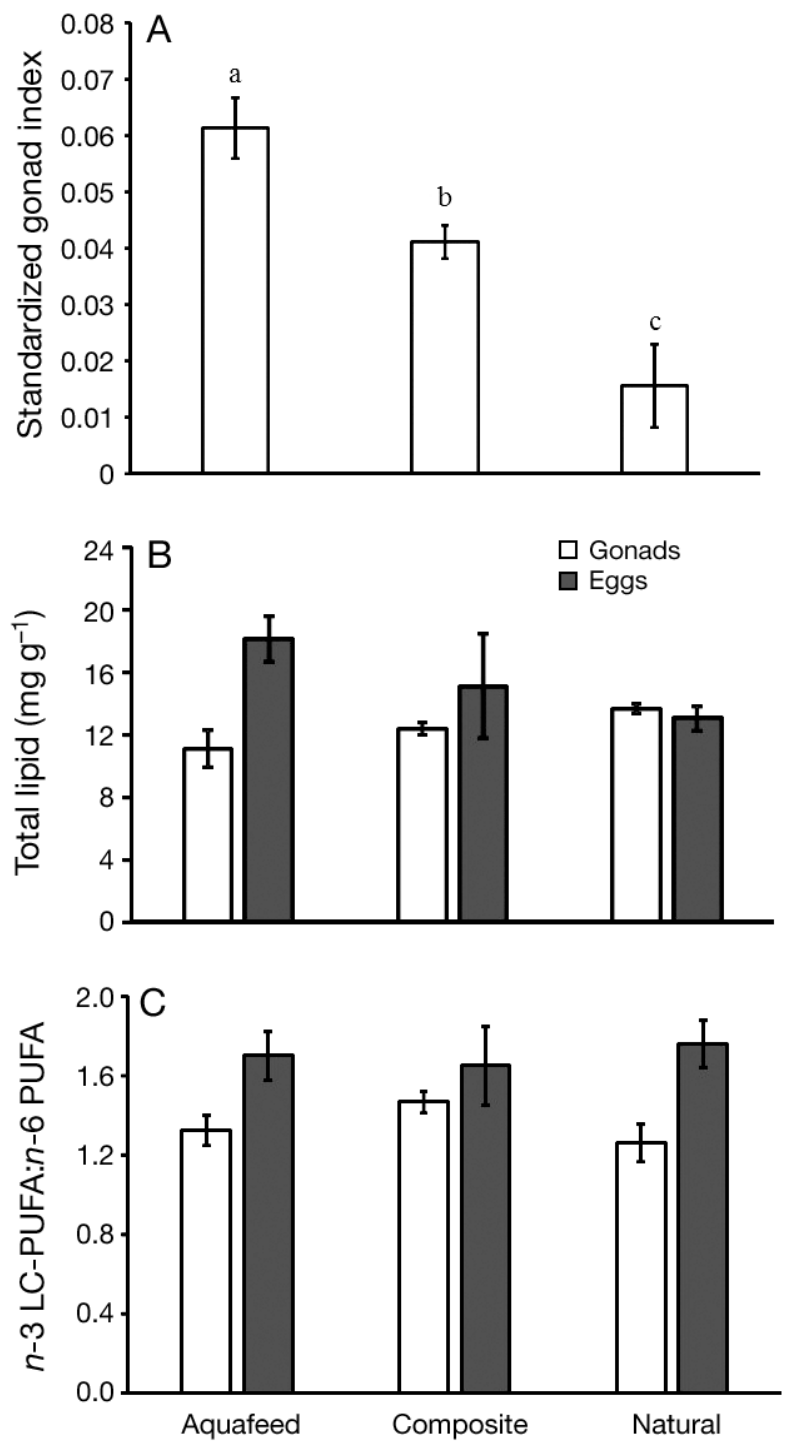

Fig. 3. Mean $( \pm \mathrm{SE})$ effects of dietary treatment on Gracilechinus acutus lipid content measured as (A) standardized gonad index, (B) total lipid (mg lipid $\mathrm{g}^{-1}$ dry mass) in gonads and eggs, and (C) n-3 LC-PUFA:n-6 PUFA in gonads and eggs. Superscript letters in (A) denote significant treatment effects
$0.9)$ was similar across diets, despite the $n-3$ LCPUFA:n-6 PUFA ratio being approximately double in natural feed, compared with the aquafeed or composite feeds (Fig. 3C, Table 1). Eggs were more enriched in $n$-3 LC-PUFA compared with gonads for all diets, varying between 1.65 and 1.75, which was also the $n-3$ LC-PUFA: $n-6$ PUFA ratio of natural feed (Fig. 3C, Table 1). Gonad histology indicated that membrane-bound vesicles within the nutritive phagocyte were emptier in urchins fed the aquafeed or composite diet, but filled with varying granular contents in urchins fed natural feed (Fig. 4).

\section{Reproductive output model}

Model results indicate that aggregations of adult urchins at aquaculture sites will lead to a net increase in the number of $10 \mathrm{~d}$ old larvae surviving in the water column, compared with a natural scenario (Fig. 5). Larval output from $1 \mathrm{~m}^{2}$ of fjord in aquaculture locations subject to aquaculture feed or composite diets were on average 5 times greater than control locations with natural diets, although this varied between locations (Fig. 5). Larval outputs under the most ecologically relevant composite diet were $21 \%$ greater than for the aquaculture feed diet due to greater survivorship of larvae.

\section{DISCUSSION}

We demonstrated that high densities of sea urchins aggregate at aquaculture sites, while control sites had far lower urchin densities. High densities of urchins at aquaculture sites could form through attraction and aggregation of larval, juvenile or adult urchins, or via reduced mortality of urchins at aquaculture sites compared with controls, or a combination of these processes. While we could not separate mechanisms leading to aggregations of urchins, aquaculture sites create suitable conditions for the formation and persistence of urchin barrens, with possible wider consequences for fjord ecosystems. The occurrence of dense populations of urchins at aquaculture sites places them directly at the source of the greatest waste deposition, which they readily consume (White et al. 2017). The trophic subsidy is qualitatively different from natural feeds and creates changes in the reproductive capabilities of urchins that receive it. When abundance data and reproductive outputs data are combined, each aquaculture site can be a population source for urchins, produc- 


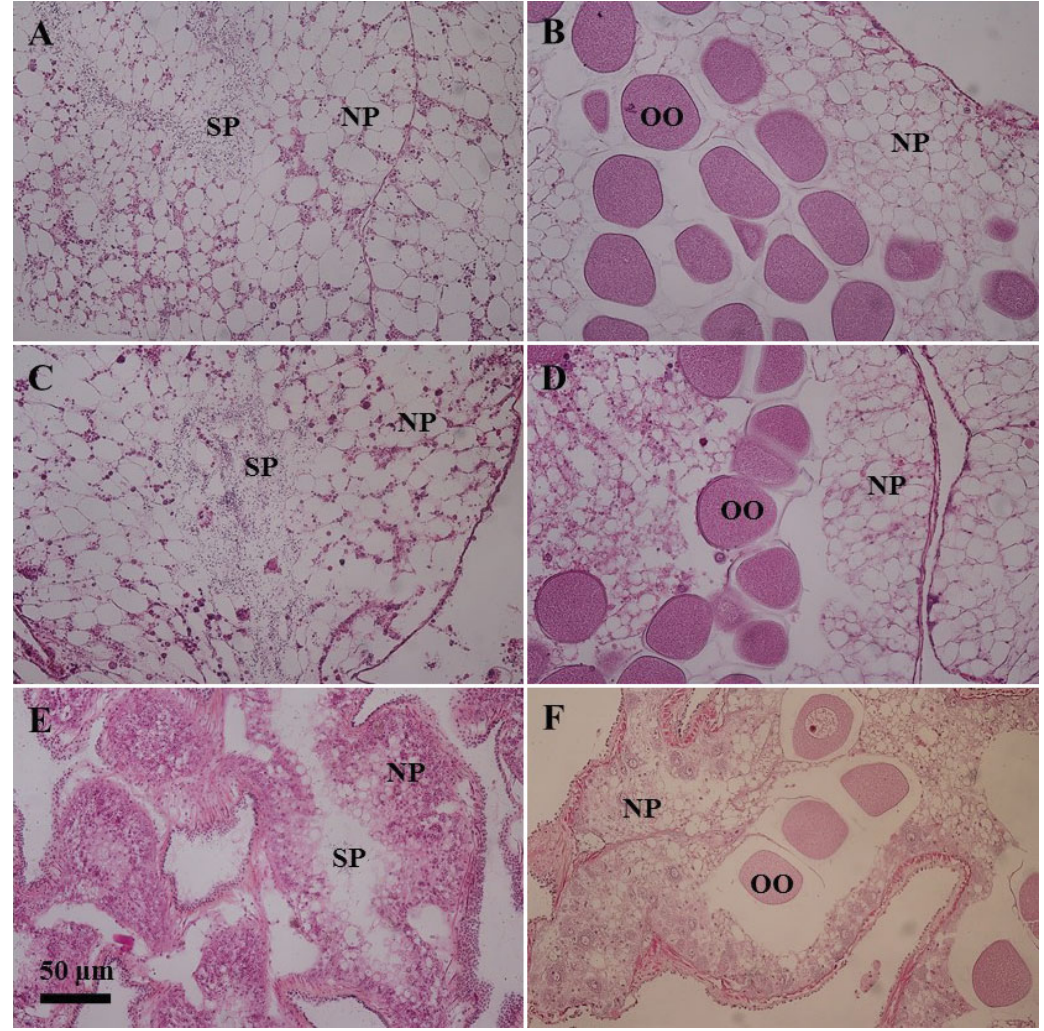

Fig. 4. Histological examination of the gonads of Gracilechinus acutus using haemotoxylin erythrosin saffron stain as (A) male urchins fed the aquafeed treatment, (B) female urchins fed the aquafeed treatment, (C) male urchins fed the composite treatment, (D) female urchins fed the composite treatment, (E) male urchins fed the natural treatment and (F) female urchins fed the natural treatment. NP: nutritive phagocyte; OO: oocyte; SP: spermatozoa. Scale bar $=50 \mu \mathrm{m}$

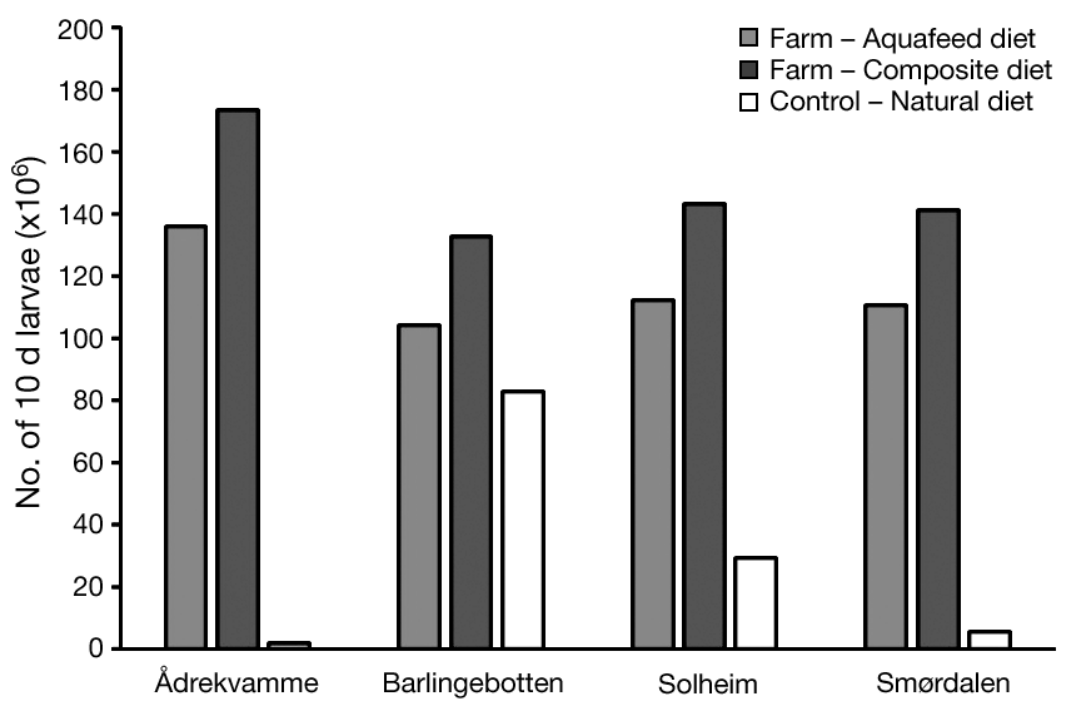

Fig. 5. Model output showing the number of Gracilechinus acutus $10 \mathrm{~d}$ old larvae $\left(\times 10^{6}\right)$ present in the water column from a $1 \mathrm{~m}^{2}$ section of fjord in both aquaculture and control locations, under aquafeed (light grey), composite (dark grey) and control (white) dietary conditions ing 5 times more competent $10 \mathrm{~d}$ old larvae than control sites in the same fjord. Overall, consuming an aquaculture waste subsidy affects both individuals and populations of urchins, with potential ecological consequences.

\section{Effects on individuals}

Gonad indices of Gracilechinus acutus differed corresponding to the proportion of aquafeed in the dietary treatments. As gonads act as both a reproductive and an energy storage organ in sea urchins (Marsh \& Watts 2001, Walker et al. 2001), it is unsurprising that increases in dietary carbohydrate, protein and lipid lead to larger gonad indices. An energy-rich subsidy in the wild could have implications for enhanced survival during periods of food limitation, with urchins able to reabsorb energy stores when required to meet metabolic demands (Kelly 2000). Given the importance of maternal lipid reserves in facilitating larval survival (Byrne et al. 2008, Carboni et al. 2012), offspring from the aquafeed and composite dietary treatments would have been expected to have higher fertilisation and larval success rates. Paradoxically, the opposite occurred, with the proportion of aquafeed in maternal diet corresponding to smaller eggs and decreased fertilisation and larval survival at $10 \mathrm{~d}$. While urchins in the experiment were never food limited, those fed lowerenergy diets may supply resources to reproductive development in favour of somatic growth (Kelly \& Cook 2001, Otero-Villanueva et al. 2004). Given the lower lipid values of the natural experimental diet, but similar lipid concentrations in eggs compared with other diets, combined with larger egg size, there is some evidence this occurred in females fed natural diets.

The biochemical composition of diet may play an important role in the increased success of larvae produced 
by females fed natural diets. Lipid composition of the aquafeeds used were high in terrestrially derived $\mathrm{C}_{18}$ PUFA and low in marine-derived $\geq C_{20} n-3$ LC-PUFA, which is the current global standard for grow-out feeds in commercial finfish aquaculture (Turchini et al. 2009, Nichols et al. 2014). Increased levels of terrestrially derived oil in the diet, particularly increased $n$-6 PUFA, led to decreased sperm viability and fertilisation rates of guppies (Rahman et al. 2015) and urchins (White et al. 2016), while high intake of marinederived $n$-3 LC-PUFA promotes growth and development of urchin larvae (Carboni et al. 2012). There was no difference in the $n$-3 LC-PUFA:n-6 PUFA ratio of gonads or eggs among dietary treatments; however, G. acutus can selectively accumulate particular fatty acids from diet or biosynthesize essential fatty acids from dietary substrates (White et al. 2017). This considerably alters the fatty acid profile of body tissue compared with diet and can help overcome limitations in essential fatty acids (White et al. 2017). However, there is a limit to this capacity, and there are unknown energetic costs (Laurel et al. 2010).

Performance of larvae may also be influenced by other feed components. Although not measured in this study, protein is important for successful larval development and survival in sea urchins (Marsh \& Watts 2001) and interacts with lipid during uptake and assimilation (Cook et al. 2007). As eggs produced by G. acutus females fed natural diet are larger, yet contain similar concentrations of lipids to the other diets, they may contain a higher proportion of another metabolic component important to survival. In the wild, G. acutus forms dense aggregations on detrital macroalgae and a preference for macroalgae is common in omnivorous urchins (e.g. Echinometra chloroticus, Barker 2001; Psammechinus miliaris, Kelly \& Cook 2001). Therefore, specific compounds that improve larval development may occur in algal components of the natural diet, enhancing its overall nutritional value and therefore larval success. Alternatively, another component of the aquaculture feed itself may be detrimental to larval success.

\section{Population-level effects}

Regardless of the physiological mechanism, female G. acutus fed diets containing salmon aquaculture feed produced larvae with lower survival rates at $10 \mathrm{~d}$ than those fed a natural diet. Given the dense aggregations of G. acutus at farms, by reducing reproductive outcomes, aquaculture waste may act as an ecological trap (Robertson \& Hutto 2006, Hale \& Swearer 2016). The exact effect on populations will be a balance between the physiological benefits that the resource provides to individuals and populations, versus any detrimental effects on reproductive outputs. Our reproductive model suggested that the numbers of sea urchins at aquaculture sites negate any detrimental effects that consuming aquaculture feed have on offspring. Barren areas are common where dense aggregations of $G$. acutus are found, with urchins able to maintain a lower limit of kelp vegetation (Husa et al. 2014). Urchins were smaller at aquaculture compared with control locations, with reduced body sizes typical where densities of urchins are high (Levitan 1989, 1991). Subsequently, the energetic benefit of the resource to the individual may be limited due to high competition for the trophic subsidy. However, the overall net effect on the population is positive, as high population densities in broadcast spawners such as $G$. acutus can ensure fertilisation success before gametes become diluted (Quinn et al. 1993, Wahle \& Peckham 1999, Gascoigne et al. 2009). As such, increased population densities of $G$. acutus around aquaculture sites will increase larval abundances, despite animals being smaller compared with more isolated animals at control locations (Levitan 1991, Levitan et al. 1992, Lundquist \& Botsford 2011). As our model could not account for this important Allee effect, relative fertilisation success at aquaculture sites is likely underestimated.

Given the larval retention time for G. acutus is approximately 50 d (MacBride 1903, Gage et al. 1986), larvae from aquaculture-associated aggregations will disperse widely and settle beyond the aquaculture zone where they were released. While this could increase the spatial influence that aquaculture has on urchin populations, it may also dilute its effect. However, in a typical fjordal circulation pattern, where a thin low-salinity surface layer flows seaward, and with a compensatory landward flow beneath this, a large proportion of larvae are likely to be entrained within the fjord. This phenomenon occurs for the sea urchin Evechinus chloroticus in New Zealand fjord systems (Lamare 1998, Wing et al. 2003), which produces similarly small, negatively buoyant planktotrophic larvae to G. acutus with similar development times (Lamare 1998, Tyler \& Young 1998). If entrainment of larvae occurs in fjord systems with intensive aquaculture, increases in larval production will be concentrated, with effects compounded over time.

A more precise estimation of the impact of aquaculture on $G$. acutus populations across larger spatial scales may be possible with further information on a 
number of key variables, such as the extent of suitable settling habitat within the fjord, and the spatial and temporal persistence of aggregations around aquaculture sites. The link between pelagic and benthic systems and factors that may influence successful metamorphosis and settling of $G$. acutus larvae will also aid better estimates of the overall impact that an aquaculture subsidy may have on a fjordwide scale. Moreover, as our survey depth only extended to $10 \mathrm{~m}$ and $G$. acutus has a depth range that potentially reaches $2000 \mathrm{~m}$ (Tyler \& Young 1998), we were only able to capture a small proportion of the total aggregation in our survey. Whether the aquaculture subsidy actually acts as attractant, causing G. acutus to migrate to shallower depths around farms, requires further investigation.

The reproductive output model predicted an increase in the number of larvae in the water column each year due to aquaculture. When tracing assimilation of farm waste, White et al. (2017) found urchins consumed feed up to $350 \mathrm{~m}$ from farms. Using this value as the demarcation between 'aquaculture affected' and normal fjord, we can examine broader effects of urchin aggregations around farms. Given the total coastline of Masfjorden $(70 \mathrm{~km})$, this results in $6 \%$ of coastline within the fjord affected by aquaculture. When coupled with outputs from the reproductive model, this equates to an increase of approximately $20 \%$ in the amount of urchin larvae in the fjord system each year. Given that aquaculture commenced in the 1970s in Norway (Husa et al. 2014) and has expanded with time, a long-term interaction of this nature has broad implications for the creation of urchin larvae population sources in fjord ecosystems. Only observational data exist on urchin populations prior to the commencement of aquaculture in the fjords (Jorde \& Klavestad 1963), making it difficult to fully assess the long-term impact of aquaculture on urchins. However, the wider ecological effects of urchin aggregations, such as barren formation, suggest that enhanced production of urchin larvae on a fjord-wide scale has the potential to drive ecosystem-level change.

\section{CONCLUSIONS AND IMPLICATIONS FOR MANAGEMENT}

Sea urchins occur naturally in Norwegian fjords, and localised barren areas existed due to G. acutus overgrazing prior to the introduction of large-scale salmon aquaculture (Jorde \& Klavestsd 1963, Husa et al. 2014). However, our results show that these events can be promoted by aquaculture subsidies. Aquaculture waste is an energy-rich trophic subsidy and can stimulate dense aggregations of urchins at farm sites. Consumption of aquaculture waste alters biochemical physiology and reduces larval success; however, modelling indicates that adult density effects will supersede any detrimental effects on reproduction in terms of net reproductive output. Like many urchin species, G. acutus is an ecosystem engineer that can drive ecosystem-level change via barren formation through overgrazing on kelp. Risk-based assessment on appropriate spatial and temporal scales is required to fully understand the extent of interactions between aquaculture-derived trophic subsidies and populations of urchins in fjord ecosystems.

The lack of regional baseline data for benthic communities, on both soft and hard substrate, is not an uncommon scenario in environments where aquaculture has expanded from small-scale operations to multi-farm operations with high regional densities. An understanding of localised impacts may be adequate where aquaculture operations are small. However, when aquaculture operates at high regional densities, diffuse effects can become additive and influence change on a much broader spatial scale, where unfortunately, baseline data are often lacking. As aquaculture continues to expand, it is critical to capture a robust environmental baseline through which broad-scale changes can be evaluated in the future. Further exploration of the interaction between G. acutus and finfish aquaculture is warranted to fully assess and subsequently mitigate any consequences for broader ecosystem function in the Norwegian fjords.

Acknowledgements. This work was supported by a University of Melbourne Overseas Research Experience Scholarship (ORES) and the Norwegian Research Council (Project no. 228871). The authors thank S. A. Olsen, K. A. Kvestad, B. Haugland Taraldset, S. Woodcock, N. Keeley, B. Muir, F. Oppedal, $\varnothing$ and Ingrid Uglenes Fiksdal. Strand and T. Strohmeier and the technical staff at the Institute of Marine Research (IMR), Matre, for assistance.

\section{LITERATURE CITED}

Anderson MJ, Gorley RN, Clarke KR (2008) PERMANOVA+ for PRIMER: guide to software and statistical methods. PRIMER-E, Plymouth

Bannister RJ, Valdemarsen T, Hansen PK, Holmer M, Ervik A (2014) Changes in benthic sediment conditions under an Atlantic salmon farm at a deep, well-flushed coastal site. Aquacult Environ Interact 5:29-47

Bannister RJ, Johnsen IA, Asplin L, Kutti T, Hansen PK (2016) Near- and far-field dispersal modelling of organic waste from Atlantic salmon aquaculture in fjord systems. ICES J Mar Sci 73:2408-2419 
Barker MF (2001) The ecology of Evechinus chloroticus. In: Lawrence JM (ed) Edible sea urchins: biology and ecology. Elsevier, Amsterdam, p 245-260

* Broch OJ, Daae RL, Ellingsen IH, Nepstad R, Bendiksen EA, Reed JL, Senneset G (2017) Spatiotemporal dispersal and deposition of fish farm wastes: a model study from central Norway. Front Mar Sci 4:199

Burridge L, Weis JS, Cabello F, Pizarro J, Bostick K (2010) Chemical use in salmon aquaculture: a review of current practices and possible environmental effects. Aquaculture 306:7-23

Byrne M, Sewell MA, Prowse TAA (2008) Nutritional ecology of sea urchin larvae: influence of endogenous and exogenous nutrition on echinopluteal growth and phenotypic plasticity in Tripneustes gratilla. Funct Ecol 22:643-648

Carboni S, Vignier J, Chiantore M, Tocher DR, Migaud H (2012) Effects of dietary microalgae on growth, survival and fatty acid composition of sea urchin Paracentrotus lividus throughout larval development. Aquaculture 324-325:250-258

Carroll ML, Cochrane S, Fieler R, Velvin R, White P (2003) Organic enrichment of sediments from salmon farming in Norway: environmental factors, management practices, and monitoring techniques. Aquaculture 226: $165-180$

Cook EJ, Kelly MS (2007) Effect of variation in the protein value of the red macroalga Palmaria palmata on the feeding, growth and gonad composition of the sea urchins Psammechinus miliaris and Paracentrotus lividus (Echinodermata). Aquaculture 270:207-217

Cook EJ, Hughes AD, Orr H, Kelly MS, Black KD (2007) Influence of dietary protein on essential fatty acids in the gonadal tissue of the sea urchins Psammechinus miliaris and Paracentrotus lividus (Echinodermata). Aquaculture 273:586-594

Dempster T, Uglem I, Sanchez-Jerez P, Fernandez-Jover D, Bayle-Sempere J, Nilsen R, Bjorn PA (2009) Coastal salmon farms attract large and persistent aggregations of wild fish: an ecosystem effect. Mar Ecol Prog Ser 385: $1-14$

Dempster T, Sanchez-Jerez P, Fernandez-Jover D, BayleSempere J, Nilsen R, Bjorn PA, Uglem I (2011) Proxy measures of fitness suggest coastal fish farms can act as population sources and not ecological traps for wild gadoid fish. PLOS ONE 6:e15646

Directorate of Fisheries (2016) Aquaculture statistics. www. fiskeridir.no/English/Aquaculture/Statistics/Atlanticsalmon-and-rainbow-trout (accessed September 2016)

Fernandez-Jover D, Martinez-Rubio L, Sanchez-Jerez P, Bayle-Sempere JT and others (2011a) Waste feed from coastal fish farms: a trophic subsidy with compositional side-effects for wild gadoids. Estuar Coast Shelf Sci 91: $559-568$

Fernandez-Jover D, Arechavala-Lopez P, Martinez-Rubio L, Tocher DR and others (2011b) Monitoring the influence of marine aquaculture on wild fish communities: benefits and limitations of fatty acid profiles. Aquacult Environ Interact 2:39-47

Gage JD, Tyler PA, Nichols D (1986) Reproduction and growth of Echinus acutus var. norvegicus Duben \& Koren and E. elegans Duben \& Koren on the continental slope off Scotland. J Exp Mar Biol Ecol 101:61-83

Gascoigne J, Berec L, Gregory S, Courchamp F (2009) Dangerously few liaisons: a review of mate-finding Allee effects. Popul Ecol 51:355-372
Gorman D, Russell BD, Connell SD (2009) Land-to-sea connectivity: linking human-derived terrestrial subsidies to subtidal habitat change on open rocky coasts. Ecol Appl 19:1114-1126

Graham MH (2004) Effects of local deforestation on the diversity and structure of Southern California giant kelp forest food webs. Ecosystems 7:341-357

Hale R, Swearer SE (2016) Ecological traps: current evidence and future directions. Proc R Soc B 283:20152647

*Husa V, Steen H, Sjotun K (2014) Historical changes in macroalgal communities in Hardangerfjord (Norway). Mar Biol Res 10:226-240

Jorde I, Klavestad N (1963) The natural history of the Hardangerfjord. 4. The benthonic algal vegetation. Sarsia 9:1-100

Keeley NB, Forrest BM, Crawford C, Macleod CK (2012) Exploiting salmon farm benthic enrichment gradients to evaluate the regional performance of biotic indices and environmental indicators. Ecol Indic 23:453-466

Kelly MS (2000) The reproductive cycle of the sea urchin Psammechinus miliaris (Echinodermata: Echinoidea) in a Scottish sea loch. J Mar Biol Assoc UK 80:909-919

Kelly MS, Cook EJ (2001) The ecology of Psammechinus miliaris. In: Lawrence JM (ed) Edible sea urchins: biology and ecology. Elsevier Science, Amsterdam, p 217-224

Kutti T, Hansen PK, Ervik A, Hoisaeter T, Johannessen P (2007) Effects of organic effluents from a salmon farm on a fjord system. II. Temporal and spatial patterns in infauna community composition. Aquaculture 262:355-366

Lamare MD (1998) Origin and transport of larvae of the sea urchin Evechinus chloroticus (Echinodermata: Echinoidea) in a New Zealand fiord. Mar Ecol Prog Ser 174: $107-121$

Larsen S, Muehlbauer JD, Marti E (2016) Resource subsidies between stream and terrestrial ecosystems under global change. Glob Change Biol 22:2489-2504

* Laurel BJ, Copeman LA, Hurst TP, Parrish CC (2010) The ecological significance of lipid/fatty acid synthesis in developing eggs and newly hatched larvae of Pacific cod (Gadus macrocephalus). Mar Biol 157:1713-1724

KLevitan DR (1989) Density dependent size regulation in Diadema antillarum - effects on fecundity and survivorship. Ecology 70:1414-1424

* Levitan DR (1991) Influence of body size and population density on fertilization success and reproductive output in a free-spawning invertebrate. Biol Bull 181:261-268

* Levitan DR, Sewell MA, Chia FS (1992) How distribution and abundance influence fertilization success in the sea urchin Stronglyocentrotus droebachiensis. Ecology 73: 248-254

Ling SD (2008) Range expansion of a habitat-modifying species leads to loss of taxonomic diversity: a new and impoverished reef state. Oecologia 156:883-894

* Lundquist CJ, Botsford LW (2011) Estimating larval production of a broadcast spawner: the influence of density, aggregation, and the fertilization Allee effect. Can J Fish Aquat Sci 68:30-42

MacBride EW (1903) The development of Echinus esculentus, together with some points in the development of E. miliaris and E. acutus. Philos Trans R Soc B 195:285-327

* Macleod CK, Crawford CM, Moltschaniwskyj NA (2004) Assessment of long term change in sediment condition after organic enrichment: defining recovery. Mar Pollut Bull 49:79-88 
Marcarelli AM, Baxter CV, Mineau MM, Hall RO (2011) Quantity and quality: unifying food web and ecosystem perspectives on the role of resource subsidies in freshwaters. Ecology 92:1215-1225

Marczak LB, Thompson RM, Richardson JS (2007) Metaanalysis: trophic level, habitat, and productivity shape the food web effects of resource subsidies. Ecology 88: $140-148$

Marsh AG, Watts SA (2001) Energy metabolism and gonad development. In: Lawrence JM (ed) Edible sea urchins: biology and ecology. Elsevier Science, Amsterdam, p $27-42$

Nichols PD, Glencross B, Petrie JR, Singh SP (2014) Readily available sources of long-chain omega-3 oils: Is farmed Australian seafood a better source of the good oil than wild-caught seafood? Nutrients 6:1063-1079

Olsen SA, Ervik A, Grahl-Nielsen O (2012) Tracing fish farm waste in the northern shrimp Pandalus borealis (Kroyer, 1838) using lipid biomarkers. Aquacult Environ Interact 2:133-144

Oro D, Genovart M, Tavecchia G, Fowler MS, MartinezAbrain A (2013) Ecological and evolutionary implications of food subsidies from humans. Ecol Lett 16:1501-1514

* Otero-Villanueva MDM, Kelly MS, Burnell G (2004) How diet influences energy partitioning in the regular echinoid Psammechinus miliaris; constructing an energy budget. J Exp Mar Biol Ecol 304:159-181

Parrish CC (2009) Essential fatty acids in aquatic food webs. Springer, New York, NY

Quinn GP, Keough MJ (2002) Experimental design and data analysis for biologists. Cambridge University Press, Cambridge

Quinn JF, Wing SR, Botsford LW (1993) Harvest refugia in marine invertebrate fisheries - models and applications to the red sea urchin, Stronglyocentrotus franciscanus. Am Zool 33:537-550

Rahman MM, Gasparini C, Turchini GM, Evans JP (2015) Testing the interactive effects of carotenoids and polyunsaturated fatty acids on ejaculate traits in the guppy Poecilia reticulata (Pisces: Poeciliidae). J Fish Biol 86: 1638-1643

Riera R, Sanchez-Jerez P, Rodriguez M, Monterroso O (2014) Artificial marine habitats favour a single fish species on a long-term scale: the dominance of Boops boops around off-shore fish cages. Sci Mar 78:505-510

Robertson BA, Hutto RL (2006) A framework for understand-

Editorial responsibility: Pablo Sánchez Jerez, Alicante, Spain ing ecological traps and an evaluation of existing evidence. Ecology 87:1075-1085

Samuelsen OB, Lunestad BT, Hannisdal R, Bannister R and others (2015) Distribution and persistence of the anti sealice drug teflubenzuron in wild fauna and sediments around a salmon farm, following a standard treatment. Sci Total Environ 508:115-121

Sheppard Brennand H, Soars N, Dworjanyn SA, Davis AR, Byrne $M$ (2010) Impact of ocean warming and ocean acidification on larval development and calcification in the sea urchin Tripneustes gratilla. PLOS ONE 5:e11372

* Taranger GL, Karlsen O, Bannister RJ, Glover KA and others (2015) Risk assessment of the environmental impact of Norwegian Atlantic salmon farming. ICES J Mar Sci 72: 997-1021

Turchini GM, Torstensen BE, Ng WK (2009) Fish oil replacement in finfish nutrition. Rev Aquacult 1:10-57

* Twining CW, Brenna JT, Hairston NG, Flecker AS (2016) Highly unsaturated fatty acids in nature: what we know and what we need to learn. Oikos 125:749-760

* Tyler P, Young CM (1998) Temperature and pressure tolerances in dispersal stages of the genus Echinus (Echinodermata: Echinoidea): prerequisites for deep-sea invasion and speciation. Deep Sea Res II 45:253-277

UNEP (United Nations Environment Programme) (2016) World Ocean Assessment: Overview. GRID-Arendal, Arendal

Wahle RA, Peckham SH (1999) Density-related reproductive trade-offs in the green sea urchin, Strongylocentrotus droebachiensis. Mar Biol 134:127-137

Walker CW, Unuma T, McGinn NA, Harrington LM, Lesser MP (2001) Reproduction of sea urchins. In: Lawrence JM (ed) Edible sea urchins: biology and Ecology. Elsevier Science, Amsterdam, p 5-26

* White CA, Dworjanyn SA, Nichols PD, Mos B, Dempster T (2016) Future aquafeeds may compromise reproductive fitness in a marine invertebrate. Mar Environ Res 122: $67-75$

*White CA, Bannister RJ, Dworjanyn SA, Husa V, Nichols PD, Kutti T, Dempster T (2017) Consumption of aquaculture waste affects the fatty acid metabolism of a benthic invertebrate. Sci Total Environ 586:1170-1181

*Wing SR, Gibbs MT, Lamare MD (2003) Reproductive sources and sinks within a sea urchin, Evechinus chloroticus, population of a New Zealand fjord. Mar Ecol Prog Ser 248:109-123

Submitted: December 12, 2017; Accepted: May 2, 2018 Proofs received from author(s): June 12, 2018 